\title{
Pendapatan Nelayan Pencari Kepiting Bakau Di Desa Pasar Ngalam Kecamatan Air Periukan Kabupaten Seluma Propinsi Bengkulu
}

\author{
*Rita Feni, Edy Marwan, Fithri Mufriantie, Sukardi \\ Program Studi Agribisnis Fakultas Pertanian dan Peternakan Univ.Muhammadiyah Bengkulu \\ Kampus 1 UMB Jl. Bali Kota Bengkulu Telp. (0736) 22765 \\ *email korespondensi : ritafeniafif@gmail.com
}

\begin{abstract}
This study aimed to determine whether the mangrove crab seeker business in Pasar Ngalam Village, Air Periukan District, Seluma Regency was profitable. The method used in this research was the census method, and questionnaire was used as an instrument to retrieve data. On the other hand, 19 mangrove crabs seekers were token as respondents of this study. The results of analysis indicated that the average income earned by the mangrove crab seeker in Pasar Ngalam Village, Air Periukan District, Seluma Regency was about Rp.74.966,20 per month.
\end{abstract}

Keywords : income, mangrove, crab

\begin{abstract}
Abstrak. Penelitian ini bertujuan untuk mengetahui pendapatan nelayan pencari kepiting bakau di Desa Pasar Ngalam Kecamatan Air Periukan Kabupaten Seluma. Metode penelitian yang digunakan adalah metode sensus dan instrument untuk pengambilan data menggunakan kuisioner. Adapun responden pada penelitian ini berjumlah 19 orang nelayan pencari kepiting bakau di daerah penelitian. Hasil penelitian menujukan bahwa pendapatan yang diperoleh pencari kepiting bakau di Desa Pasar Ngalam Kecamatan Air Periukan Kabupaten Seluma rata-rata sebesar Rp 74966,20/bulan.
\end{abstract}

Kata kunci : pendapatan, bakau, kepiting

\section{PENDAHULUAN}

Indonesia adalah negara kepulauan terbesar di dunia dengan jumlah pulau sebanyak 17.508 pulau, garis pantai sepanjang $81.000 \mathrm{~km}$, luas lautan 5,8 juta km (75\% dari total luas wilayah Indonesia). Di wilayah daratan tedapat perairan umum (sungai, rawah, danau, waduk dan genangan air lainnya) seluas 54 juta ha atau 0,54 juta $\mathrm{km}^{2}$ (27\% dari total wilayah daratan indonesia). Sebagai negara maritim, indonesia memiliki potensi pembangunan (ekonomi) kelautan dan perikanan yang sangat besar dan beragam. Sedikitnya terdapat sembilan sektor ekonomi yang dapat dikembangkan guna memajukan dan memakmurkan indonesia, yaitu; perikanan tangkap, perikanan budidaya, industri bioteknologi kelautan, pertambangan dan energi, parawisata bahari, transportasi laut, industri dan jasa maritim, pulau-pulau kecil, dan sumber daya non kovensional (Dahuri, 2005. dalam H. kordi K.M, Ghufron, 2010). Sektor kelautan dan perikanan merupakan salah satu sektor ekonomi yang memiliki peranan dalam pembangunan ekonomi nasional, khususnya dalam menyediakan bahan protein, perolehan devisa, dan penyediaan lapangan kerja. (Ekonomi kelautan, Mulyadi (2007)

Provinsi Bengkulu memiliki potensi yang begitu besar di bidang perikanan. Luas wilayah Provinsi Bengkulu mencapai $\pm 32.254,53 \mathrm{~km}^{2}$ dengan luas daratan $\pm 19.919,33 \mathrm{~km}^{2}$ dan luas perairan (laut) mencapai \pm $12.335,2 \mathrm{~km}^{2}$ dengan panjang garis pantai mencapai $\pm 525 \mathrm{~km}$. Saat ini Provinsi Bengkulu terdiri dari 9 Kabupaten dan 1 kota, dimana 6 kabupaten dan 1 kota termasuk dalam wilayah pesisir. Dengan luas wilayah tersebut, Provinsi Bengkulu mempunyai potensi di bidang kelautan dan perikanan baik perikanan tangkap, budidaya maupun pengolahan perikanan yang cukup besar, sehingga dapat menjadi peluang investasi yang menjanjikan (Anonim,2018).

Kabupaten Seluma merupakan salah satukabupaten yang berpotensi dalam usaha perikanan di propinsi Bengkulu. Dengan pantai sepanjang $\pm 76 \mathrm{Km}$ dengan lebar 4 mil sehingga luas wilayah lautan adalah $486,4 \mathrm{Km}$ maka terbuka luas bagi nelayan Kabupaten Seluma untuk mengembangkan usaha Perikanan Tangkap. Salah satu produk perikanan yang menjadi matapencaharian masyarakat di Seluma adalah kepiting bakau. Produksi Kepiting Bakau di Kabupaten Seluma pada tahun 2015 adalah sebesar 25 ton. Kabupaten Seluma merupakan Kabupaten pesisir pantai yang memiliki hutan bakau sebesar 6.165,8/ha.

Salah satu Desa di kabupaten Seluma adalah desa Pasar Ngalam kecamatan Air Periukan yang terletak di daerah pesisir pantai Samudra Hindia yang jaraknya 47 kilometer dari pusat kota Bengkulu merupakan desa yang banyak masyarakatnya bermatapencaharian sebagai nelayan pencari kepiting bakau. Hutan bakau di daerah ini dapat memberikan penghasilan bagi masyarakat sekitar dengan kekayaan alamnya yang melimpah seperti kepiting bakau.

Berdasarkan latar belakang inilah maka peneliti meneliti tentang 'Analisis Pendapatan Nelayan Pencari Kepiting Bakau Di Desa Pasar Ngalam Kecamatan Air Periukan Kabupaten Seluma Propinsi Bengkulu'. 


\section{METODOLOGI PENELITIAN}

Kegiatan penelitian ini dilakukan di Desa Pasar Ngalam Kecamatan Air Periukan Kabupaten Seluma Propinsi Bengkulu, dengan pertimbangan di daerah tersebut banyak masyarakatnya bermatapencaharian sebagai nelayan pencari kepiting bakau.

Responden dalam penelitian ini adalah nelayan pencari kepiting bakau di Desa Pasar Ngalam sebanyak 19 orang, yang merupakan keseluruhan dari anggota populasi nelayan di daerah tersebut, sehingga metode penentuan responden dalam penelitian ini adalah metode sensus.

Teknik pengumpulan data dan informasi dalam penelitian ini meliputi (1)Observasi, yaitu dengan melakukan pengamatan langsung terhadap jalannya operasional dan lokasi penelitian (2) Wawancara yaitu dengan melakukan wawancara langsung kepada nelayan kepiting bakau sebagai responden

Data yang dikumpulkan dalam penelitian ini adalah adalah (1)Data Primer, yaitu data diperoleh dan dihimpun secara langsung dari sumbernya. Data primer dapat berbentuk opini subjek secara individual atau kelompok, dan hasil observasi, wawancara dengan membuat beberapa pertanyaan dalam bentuk kuisioner (2)Data Sekunder, yaitu data yang diambil secara tidak langsung dari lembaga/ instansi yang berkaitan dengan masalah penelitian. Data sekunder umumnya berbentuk catatan atau laporan data dokumentasi oleh lembaga tertentu yang dipublikasikan.

Analisis data yang digunakan adalah analisis pendaptan yang secara matematis perhitungan pendapatan nelayan sebagai berikut :

$$
\begin{array}{ll}
\pi= & \text { TR }- \text { TC } \\
\text { TR }= & \text { Q.PQ } \\
\text { TC }= & \text { FC }+ \text { VC } \\
\text { Keterangan : } \\
\pi \quad=\text { Pendapatan usaha penangkap kepiting }(\mathrm{Rp}) \\
\text { TR } \quad=\text { Penerimaan }(\mathrm{Rp}) \\
\mathrm{TC} \quad=\text { Biaya }(\mathrm{Rp}) \\
\mathrm{Q} \quad=\text { Output }(\mathrm{Kg}) \\
\mathrm{PQ} & =\text { Harga outpt }(\mathrm{Rp} / \mathrm{Kg}) \\
\mathrm{Fc} & =\text { Fixed Cost } \\
\mathrm{Vc} & =\text { Variabel Cost }
\end{array}
$$

\section{Deskripsi daerah penelitian}

\section{HASIL PENELITIAN}

Luas wilayah Desa Pasar Ngalam adalah lebih kurang 4.586,42 Ha, dimana 75\% berupa daratan dan dimanfaatkan sebagai lahan pertanian dan perkebunan $10 \%$ untuk persawahan dan sisanya $15 \%$ untuk permukiman / perumahan penduduk. mayoritas penduduknya bermata pencarian sebagai petani/ kebun, buruh dan nelayan. Iklim Desa Pasar Ngalam sebagaiman di Desa lain di wilayah Provinsi Bengkulu dan Indonesia pada umumnya mempunyai iklim tropis/ musim kemarau dan penghujan.

Pasar Ngalam termasuk dalam wilayah Kecamatan Air Periukan, Kabupaten Seluma, Provinsi Bengkulu dan wilayah kerja pengelolaan kawasan masuk dalam seksi konservasi wilayah II Seluma. Cagar alam Pasar Ngalam secara geografis terletak di antara $4^{0} 00^{\prime} 10^{\prime \prime}-4005$ '42' LS dan $102^{\circ} 18^{\prime} 59^{\prime}$ '- $102^{0} 25^{\prime} 00^{\prime}$ 'BT. Hutan Suaka Alam (HSA) Pasar Ngalam ditunjuk pertama kali oleh Menteri Kehutanan pada tahun 1985, berdasarkan Surat Keputusan Menteri Kehutanan Nomor: 383/Kpts-II/1985 tanggal 27 Desember 1985 tentang penunjukan kawasan hutan di Wilayah Tingkat I Bengkulu seluas \pm 1.157 .045 ha sebagai Kawasan Hutan. Hutan Suaka Alam Pasar Ngalam memiliki luas $\pm 256,92$ ha,dengan panjang batas 14,037 km. Pada tahun 1995 dilakukan pembuatan batas sementara dan pembuatan batas definitif tahun 1996. Tahun 1997 dilakukan penegasan batas kawassan melalui orintasi batas dan rekonstruksi batas kawasan dengan panjang batas8,4 km. Pada tahun 1999, melalui surat keputusan menteri kehutanan nomor: 420/Kpts-II/1999 tanggal 15 juni 1999 tentang penunjukan kawasan hutan di wilayah Provinsi Bengkulu seluas 920,96 ha. Hutan Suaka Pasar Ngalam ditunjuk sebagai kawasan hutan dengan luas 256,92 ha(BKSDA Bengkulu, 2013)

\section{Karakteristik Responden}

1) Umur

Umur adalah salah satu faktor penting yang berpengaruh pada aktivitas dalam berusaha. 
Rita Feni, Edy Marwan, Fithri Mufriantie, Sukardi. Pendapatan Nelayan Pencari Kepiting Bakau Di Desa Pasar Ngalam Kecamatan Air Periukan Kabupaten Seluma Propinsi Bengkulu

Tabel 1.. Karakteristik Responden Menurut Kelompok Umur

\begin{tabular}{cccc}
\hline No & Karakteristik Umur (tahun) & Jumlah (orang) & Persentase (\%) \\
\hline 1 & $23-29$ & 5 & 26,32 \\
2 & $30-36$ & 7 & 36,84 \\
3 & $37-43$ & 4 & 21,05 \\
4 & $44-50$ & 3 & 15,79 \\
\hline & Jumlah & 19 & 100 \\
\hline
\end{tabular}

Tabel 1 menunjukan bahwa responden pencari kepiting bakau pada daerah penelitian ini pada kategori dalam rentang usia produktif dalam menjalankan usahanya. Presentase umur terbesar dari responden pencari kepiting bakau pada daerah penelitian berada pada kelompok umur 30-36 tahun dengan presentase 36,84\%.

\section{2) Pendidikan}

Tingkat pendidikan merupakan faktor penting terhadap pengetahuan dan keterampilan yang berpengaruh pada pendapatan. Pendidikan merupakan penunjang seseorang dalam pengetahuan dan ketrampilan terhadap teknologi dan inovasi baru yang dapat menujang keberhasilan dan meningkatkan pendapatan.

Tabel 2. Karakteristik Responden Menurut Tingkat Pendidikan Terakhir

\begin{tabular}{cccc}
\hline No & Karakteristik Pendidikan & Jumlah (orang) & Persentase (\%) \\
\hline 1 & Tidak Tamat SD & 3 & 15,79 \\
2 & SD & 5 & 26,32 \\
3 & SMP & 7 & 36,84 \\
4 & SMA & 4 & 21,05 \\
\hline
\end{tabular}

Tabel 2 menunjukan tingkat pendidikan pada daerah penelitian relatif rendah. Persentase tingkat pendidikan responden dalam penelitian terbesar berada pada tingkat SMP yaitu pada persentase $36,84 \%$. Dari hasil data identitas responden bahwa pendidikan pada daerah penelitian yang masih rendah. Rendahnya tingkat pendidikan dikarenakan tingkat kesadaran untuk melanjutkan kejenjang pendidikan yang lebih tinggi dan faktor mempengaruhi adalah keadaan ekonomi khususnya dalam memenuhi biaya sekolah. Tingkat pendidikan yang seperti ini secara tidak langsung mempengaruhi pengetahuan dan tingkat inovasi baru berkaitan dalam meningkatan pendapatan.

\section{3) Lama Berusaha}

Lama berusaha sebagai nelayan pencari kepiting bakau dalam penelitian ini merupakan faktor yang mendukung dalam menghasilkan pendapatan. Pengalaman kerja sebagai pencari merupakan proses pembelajaran dan tolak ukur di luar pendidikan formal yang mampu mendukung keberhasilan dalam memperoleh hasil tangkapan dan pendapatan. Karakteristik responden pencari kepiting bakau berdasarkan kelompok pengalaman usaha sebagai pencari pada daerah penelitian dapat dilihat pada tabel 3 dibawah ini :

Tabel 3. Karakteristik Responden Menurut Kelompok Lama Berusaha

\begin{tabular}{cccc}
\hline No & Karakteristik lama berusaha (tahun) & Jumlah (orang) & Persentase (\%) \\
\hline 1 & $3-7$ & $\mathbf{1 1}$ & 57,89 \\
2 & $8-12$ & 8 & 42,11 \\
\hline & Jumlah & $\mathbf{1 9}$ & $\mathbf{1 0 0}$ \\
\hline
\end{tabular}

Lama usaha pada hasil penelitian menujukan bahwa presentase kelompok lama usaha sebagai pencari terbesar pada kelompok lama usaha 3-7 tahun dengan prsentase yakni 57,89\% dari jumlah responden penelitian.

\section{Analisa pendapatan \\ Biaya Tetap}

Biaya tetap adalah jenis biaya yang besar kecilnya tidak tergantung pada besar kecilnya produksi. Biaya yang tetap yang dikeluarkan pencari kepiting bakau di desa pasar ngalam kecamatan air periukan kabupaten seluma adalah biaya penyusutan alat'

\section{Biaya Penyusutan Alat}

Biaya penyusutan alat adalah biaya yang harus dikeluarkan dalam berusaha yang diukur dari nilai awal dibagi umur ekonomis dan dikali pada periode produksi yang digunakan didaerah penelitian tidak habis dipakai 
dalam satu kali produksi dimana alat-alat yang digunakan tersebut terbuat dari besi, plastik, kayu sehinga untuk dapat rusak memerlukan rentang waktu cukup lama terutama pada alat-alat terbuat dari besi. Rata-rata biaya penyusutan alat yang dikeluarkan pencari dalam memperoleh produksi dalam satu bulan dapat dilihat pada tabel 10 dibawah ini :

Tabel 4. Rata-Rata Biaya Penyusutan Alat

\begin{tabular}{|c|c|c|}
\hline No. & Uraian & Nilai (Rp/Bulan) \\
\hline 1 . & Sampan & Rp. 41666,67 \\
\hline 2. & Bubu & Rp. 35767,54 \\
\hline 3. & Senter & Rp. 877,19 \\
\hline 4. & Parang & Rp. 1206,14 \\
\hline 5 . & Sepatu & Rp. 877,19 \\
\hline 6. & Cuban & Rp. 83,33 \\
\hline 7. & Karung & Rp. 166,67 \\
\hline \multirow[t]{2}{*}{ 8. Tali Troll } & Tali Troll & Rp. 1666,67 \\
\hline & Total & Rp. 82.311,40 \\
\hline
\end{tabular}

Tabel 4 menunjukkan bahwa total rata-rata biaya penyusutan alat-alat yang digunakan sebesar Rp. $82.311,40 /$ bulan. Biaya penyusutan alat yang dihitung adalah semua alat-alat yang dipakai oleh pencari untuk melakukan penangkapan kepiting bakau. Peralatan yang digunakan dalam kegiatan usaha pencari kepiting bakau meliputi: sampan, bubu, senter, parang, sepatu, cuban dan tali troll..

Biaya penyusutan terbesar pada tabel 4. adalah sampan dengan nilai penyusutan sebesar Rp. 41.666,67/bulan. Sampan merupakan alat yang digunakan untuk mencari kepiting bakau, sampan merupakan nilai alat yang terbesar yang dikeluarkan pencari dan biaya penyusutan terkecil adalah cuban sebesar Rp. 83,33. Cuban adalah alat yang mendukung nelayan pencari kepiting bakau dalam pemeliharaan alat bubu yang digunakan untuk berusaha.

\section{Biaya Variabel}

Biaya variabel adalah biaya yang besar kecilnya berhubungan langsung besarnya produksi. biaya variabel yang dikeluarkan pencari kepiting bakau di desa pasar ngalam kecamatan air periukan kabupaten seluma, dikelompokan dua kelompok yaitu menjadi biaya operasional dan biaya tenaga kerja

\section{Biaya Operasional}

Biaya Operasional adalah biaya yang dikeluarkan oleh pencari dalam melakukan setiap kali kegiatan produksi. Rata-rata biaya yang dikeluarkan nelayan pencari kepiting bakau dalam satu bulan dapat dilihat pada tabel 5 di bawah ini:

Tabel 5. Rata-Rata Biaya Operasional Yang Dikeluarkan Nelayan Pencari Kepiting Bakau

\begin{tabular}{rlll}
\hline No. & & Uraian & \multicolumn{1}{c}{ Nilai (Rp/Bulan) } \\
\hline 1. & Umpan & Rp. 184158,05 \\
2. & Tali Rafia & Rp. 7000,00 \\
3. & Batray & Rp. 13421,05 \\
4. & Rokok & Rp. 104526,32 \\
5. & Garam & Rp. 15684,21 \\
6. & Autan & Rp. 1394,74 \\
7. & BBM (bensin) & Rp. 14534,74 \\
\hline & & Total & Rp. $340.719,11$ \\
\hline
\end{tabular}

Dari tabel 5 menunjukkan bahwa total rata-rata biaya operasional yang dikeluarkan sebesar Rp. $340.719,11 /$ bulan. Biaya operasional adalah biaya yang dikeluarkan setiap kegiatan produksinya. Biaya operasional yang dikeluarkan akan berpengaruh pada pendapatan pencari kepiting didaerah penelitian. Sehingga besarnya pengeluaran biaya operasional akan mengurangi pendapatan yang diperoleh pencari.

Biaya operasional terbesar pada tabel 5 adalah umpan sebesar Rp. 184.158,05/bulan. umpan merupakan faktor penting dalam mencari kepiting dan umpan merupakan pemicu agar kepiting masuk dalam bubu yang terdapat umpan yang dipasang oleh pencari. dan biaya operasional terkecil adalah autan sebesar Rp. 1.394,74/bulan. Autan 
Rita Feni, Edy Marwan, Fithri Mufriantie, Sukardi. Pendapatan Nelayan Pencari Kepiting Bakau Di Desa Pasar Ngalam Kecamatan Air Periukan Kabupaten Seluma Propinsi Bengkulu

merupakan suatu yang mendukung pencari agar tidak tergangu oleh serangga pada saat melakukan kegiatan proses produksi.

\section{Biaya Tenaga Kerja}

Biaya tenaga kerja merupakan biaya yang dikeluarkan untuk proses produksi atau bisa dihubungkan langsung dengan barang jadi. Tenaga kerja dalam usaha pencari kepiting bakau ini tenaga kerja penangkapan, pengikatan kepiting dan pemeliharaan bubu yang di lakukan pencari kepiting. Rata - rata tenaga kerja yang dikeluarkan oleh pencari kepiting merupakan hasil dari perhitungan jam kerja, hari kerja, HOK, HKSP dan Upah yang di setarakan dengan upah buru yakni Rp 50.000,00. Rata-rata biaya yang dikeluarkan pencari dalam satu bulan dapat dilihat pada tabel 6 di bawah ini:

Tabel 6.. Rata-Rata Biaya Tenaga Kerja

\begin{tabular}{|c|c|c|}
\hline No. & Uraian & Nilai (Rp/Bulan) \\
\hline 1. & Penangkapan atau pencarian & Rp. 450986,84 \\
\hline 2 . & Pengikatan & Rp. 87500,00 \\
\hline 3. & Pemeliharaan Bubu & Rp. 31990,13 \\
\hline & Total & Rp. $\quad$ 570.476,97 \\
\hline
\end{tabular}

Pada tabel 6 menunjukkan bahwah biaya tenaga kerja terbesar adalah penangkapan atau pencarian yang dilakaukan pencari kepiting bakau. Biaya tenaga kerja ini dipengaruhi oleh waktu yang dikerjakan oleh pencari kepiting bakau, biaya tenaga kerja pada pengikatan dan pemeliharaan bubu waktu yang dikerjakan relatif sedikit di banding waktu pencarian kepiting oleh pencari kepiting bakau.

\section{Total Biaya Produksi}

Biaya Produksi merupakan penjumlahan dari seluruh biaya-biaya yang dikeluarkan oleh pencari kepiting bakau dalam proses kegiatan produksi agar dapat memperoleh hasil tangkapan kepiting bakau selama satu bulan produksi. Rata-rata total biaya yang dikeluarkan nelayan pencari kepiting bakau dapat dilihat pada tabel 7 dibawah ini.

Tabel 7. Rata-Rata Total Biaya Produksi Kepiting Bakau Dalam Satu Bulan

\begin{tabular}{|c|c|}
\hline Tipe & Nilai (Rp/Bulan) \\
\hline 1. Biaya Tetap & \\
\hline Penyusutan Alat & Rp. 82.311,40 \\
\hline 2. Biaya Variabel & \\
\hline a. Biaya Operasional & Rp. $340.719,11$ \\
\hline b. Biaya Tenaga Kerja & Rp. 570.476,97 \\
\hline Total & Rp. 993.507,48 \\
\hline
\end{tabular}

Dari tabel 7 menunjukkan bahwah rata-rata total biaya yang dikeluarkan pencari sebesar $\mathrm{Rp}$ 993.507,48/bulan. Biaya yang dikeluarkan adalah biaya tetap meliputi, Biaya penyusutan alat-alat (sampan, bubu, senter, parang, sepatu, cuban, karung dan tali troll) dan biaya Variabel meliputi biaya operasional merupakan biaya yang dikeluarkan setiap proses kegiatan produksi (umpan, tali rafia, batray, rokok, garam, autan dan bensin. Biaya tenaga kerja merupakan jumlah biaya tenaga kerja meliputi tenaga kerja (penangkapan,pengikatan dan pemeliharaan bubu) yang dihitung dalam upah buruh sebesar Rp 50.000/hari.

Biaya yang terbesar pada tabel 7 adalah biaya variabel disini adalah hasil penjumlahan biaya operasional Rp. 340.719,11/bulan dan biaya Tenaga kerja Rp. 570.476,97/bulan. Jadi Jumlah biaya variabel sebesar Rp. 911.196,08/bulan.. Jadi untuk meningkatkan pendapatan dalam usaha pencari kepiting bakau yang perlu diperhatikan dengan mengurangi biaya-biaya terutama pada biaya operasional untuk mengurangi jumlah biaya variabel yang cukup besar. Artinya besar biaya operasional yang dikeluarkan akan mengurangi pendapatan bagi nelayan pencari kepiting bakau di daerah penelitian Desa Pasar Ngalam Kecamatan Air Periukan Kabupaten Seluma.

\section{Produksi}

Produksi merupakan suatu kegiatan yang dikerjakan untuk menciptakan atau menghasilkan barang atau produk. Produksi yang dikumpulkan dalam catatan perhari dalam kuesioner guna memerlukan data produksi selama satu bulan yang di lakukan nelayan pencari kepiting bakau di Desa Pesar Ngalam Kecamatan Air Periukan Kabupaten Seluma. Rata-rata produksi kepiting bakau satu bulan dapat dlihat pada tabel 8 di bawah ini: 
Rita Feni, Edy Marwan, Fithri Mufriantie, Sukardi. Pendapatan Nelayan Pencari Kepiting Bakau Di Desa Pasar Ngalam Kecamatan Air Periukan Kabupaten Seluma Propinsi Bengkulu

Tabel 8. Rata-Rata Produksi Kepiting Bakau Permingu Dalam Satu Bulan

\begin{tabular}{lcc}
\hline & Tipe & Kg/Minggu \\
\hline 1. Minggu I & & 8,62 \\
2. Minggu II & & 9,35 \\
3. Minggu III & & 8,94 \\
4. Minggu IV & Total & 8,60 \\
\hline & & $\mathbf{3 5 , 5 1}$ \\
\hline
\end{tabular}

Pada tabel 8. Dapat dilihat bahwah rata-rata produksi kepiting bakau terbesar adalah pada minnggu II sebesar 9,35 kg/minggu dan rata-rata produksi kepiting terkecil adalah minggu IV sebesar 8,60 kg/minggu. Total produksi kepiting per minggu yang diperoleh pencari dipengaruhi oleh banyaknya jumlah produksi yang didapat oleh nelayan pencari kepiting bakau.

Produksi dihitung berdasarkan Jenis Tipe Kepiting Bakau Perbulan. Produksi kepiting bakau pada tingkat produsen pencari kepiting bakau ada empat jenis tipe kepiting bakau mulai dari jenis tipe Super, tipe A, tipe B dan tipe $\mathrm{C}$ memiliki ukuran berat yang berbeda - beda pada tiap jenis tipe kepiting yang didapatkan oleh pencari kepiting bakau di daerah penelitian.

Dari hasil pengumpulan data dan informasi kepada pencari kepiting bakau di daerah penelitian, Paroduksi kepiting pada daerah penelitian ada empat jenis tipe yang mana pencari menjual langsung kepada pedagang pengumpul kecil tingkat desa dengang tipe Super, A, B, C, produksi kepiting pada tiap jenis tipe memiliki nilai jual yang berbeda. Produksi kepiting hasil nelayan pencari kepiting bakau ini akan dipasarkan kepedagan pengumpul besar yang ada di kota Bengkulu dimana kepiting yang dipasarkan dalam kota bengkulu untuk memenuhi permintaan kepiting bakau dalam kota Bengkulu. Rata-rata produksi kepiting bakau menurut jenis tipe yang didapatkan dalam satu bulan oleh pencari kepiting bakau dapat dilihat pada tabel 9 dibawah ini.

Tabel 9. Rata-Rata Produksi Kepiting Dalam Satu Bulan menurut tipe kepiting bakau

\begin{tabular}{cccc}
\hline No. & Tipe & Tipe Syarat $\mathbf{( K g )}$ & Kg/Bulan \\
\hline 1. & Super & $>0,75$ & 1,53 \\
2. & A & $0,3-0,75$ & 8,05 \\
3. & B & $0,2-2,9$ & 10,67 \\
4. & C & $0,15-0,19$ & 15,27 \\
\hline & & Total & $\mathbf{3 5 , 5 1}$ \\
\hline
\end{tabular}

Pada tabel 9 dapat dilihat bahwa total rata-rata produksi nelayan pencari kepiting bakau sebesar 35,51 $\mathrm{Kg} / \mathrm{Bulan}$. Rata-rata produksi kepiting bakau terbesar adalah kepiting jenis tipe (C) sebesar 15,27 kg/bulan. Dan ratarata produksi kepiting bakau terkecil adalah jenis tipe kepiting (super) sebesar $1,53 \mathrm{Kg} / \mathrm{bulan}$. Kepiting jenis tipe (super) merupakan jenis tipe yang jarang di dapat oleh pencari kepiting bakau.

Produksi kepiting bakau dipengaruhi oleh faktor jumlah produksi kepiting bakau menurut tipe jenis yang didapat. produksi menurut tipe yang didapat pada tiap jenis tipe memiliki harga yang berbeda-beda. Untuk dapat menetukan harga pada tiap jenis tipe kepiting memiliki syarat dimana tiap jenis tipe kepiting bakau super lebih 7,5/ons, tipe A 3,5-7,4/ons, tipe B 2 - 2,9/ons, dan tipe C 1,5 -1,9/ons. Pada tiap jenis tipe kepiting bakau yang di dapat memiliki tingkat harga yang berbeda

Total rata-rata produksi yang didapat oleh pencari kepiting bakau selama satu bulan produksi yang berbeda beda dalam minggu pentama sampai minggu keempat dapat dilihat pada lampiran 10. Produksi kepiting bakau dalam satu bulan. Untuk Total rata-rata produksi kepiting bakau pada tabel 13 . sebesar $35,51 \mathrm{~kg} / \mathrm{bulan}$. Merupakan produksi yang dipengaruhi oleh banyaknya jumlah produksi yang di peroleh pencari kepiting bakau dalam satu bulan.

\section{Peneriman}

Peneriman adalah produksi dikali harga. Besar kecilnya peneriman di pengaruhi oleh banyak dan jenis tipe kepiting (Super, A, B dan C) yang didapat oleh pencari setiap kali produksi. Rata-rata peneriman yang diperoleh pencari dalam satu bulan dapat dilihat pada tabel 10 dibawah ini: 
Rita Feni, Edy Marwan, Fithri Mufriantie, Sukardi. Pendapatan Nelayan Pencari Kepiting Bakau Di Desa Pasar Ngalam Kecamatan Air Periukan Kabupaten Seluma Propinsi Bengkulu

Tabel 10. Rata-Rata Penerimaan Yang Diperoleh Nelayan Pencari Kepiting Bakau

\begin{tabular}{|c|c|}
\hline Tipe & Nilai (Rp/Bulan) \\
\hline 1. Super & $\begin{array}{ll}\text { Rp. } & 106.842,11\end{array}$ \\
\hline 2. $\mathrm{A}$ & Rp. $482.842,11$ \\
\hline 3. $\mathrm{B}$ & Rp. $373.357,89$ \\
\hline 4. $\mathrm{C}$ & Rp. $307.889,47$ \\
\hline Total & Rp. $1.268 .473,68$ \\
\hline
\end{tabular}

Dari tabel 10 diketahui bahwa rata-rata penerimaan nelayan pencari kepiting bakau sebesar Rp. 1268473,68/bulan. Peneriman terbesar pada tabel 10 adalah tipe kepiting (A) sebesar Rp. 482842,11/bulan. Tipe kepiting (A) merupakan tipe kepitng dengan harga Rp. 60.000/kg. dengan total rata-rata produksi 8,05 kg/bulan. Dan peneriman terkecil adalah tipe kepiting (super) sebesar Rp. 106.842,11 dengan harga Rp. 70.000/kg dengan total rata-rata produksi $1,53 \mathrm{~kg} / \mathrm{bulan}$.

Peneriman produksi kepiting bakau dipengaruhi oleh faktor jumlah produksi kepiting bakau menurut jenis tipe yang didapat. Penerimaan dari jenis tipe yang didapat memiliki harga yang berbeda-beda. Penerimaan ratarata sebesar Rp. 1.268.473,68/bulan. Merupakan penerimaan bagi pencari kepiting bakau akan tetapi peneriman ini belum termasuk pendapatan yang diterima pencari kepiting bakau peneriman ini akan di kurangi biaya produksi dimana biaya produksi berupa biaya tetap dan biaya variabel yang di keluarkan dalam satu bulan produksi. Biayabiaya yang dikeluarkan seperti, biaya tetap merupakan dari Biaya penyusutan alat meliputi alat-alat yang digunakan pencari kepiting bakau (Sampan, Bubu, Senter, Parang, Sepatu, Cuban, Karung dan Tali Troll) dan Biaya operasional meliputi biaya yaitu Umpan, Tali rafia, Batray, Rokok, Garam, Autan dan bensin dan biaya tenaga kerja. Biaya tenaga kerja ini merupakan biaya implisit di mana biaya yang tidak dikeluarkan tetapi tetap dihitung karena tenaga kerja merupakan upah bagi mereka sendiri. Biaya-biaya yang dikeluarkan pencari untuk melakukan kegiatan mencari kepiting bakau.

Peneriman yang diperoleh pencari kepiting bakau didaerah penelitian Desa Pasar Ngalam dapat berubahubah karena adanya faktor yaitu faktor cuaca, bila cuaca bagus maka penerimaan yang didapat nelayan akan lebih banyak tetapi sebaliknya bila cucaca buruk penerimaan nelayan menjadi berkurang.

\section{Pendapatan}

Pendapatan adalah selisi antara total penerimaan (total revanue) dan semua biaya produksi yang dikeluarkan (total cost). Penerimaan yang diperoleh hasil dari total produksi dalam satu bulan dikurang dengan total biaya dalam satu bulan. Rata-rata pendapatan yang diperoleh pencari dalam satu bulan dapat dilihat pada tabel 17 dibawah ini:

Tabel 11. Total Rata-rata Pendapatan Pencari Dalam Satu Bulan

\begin{tabular}{|c|c|}
\hline Tipe & Nilai (Rp/Bulan) \\
\hline Total Peneriman & Rp. $1.268 .473,68$ \\
\hline Total Biaya Produksi (TC) & Rp. $993.507,48$ \\
\hline Total & $\begin{array}{ll}\mathbf{R} & 274.966,20 \\
\end{array}$ \\
\hline
\end{tabular}

Dari tabel 11. dapat diketahui bahwa pendapatan yang diperoleh sebesar Rp 274.966,20/bulan. Jumlah pendapatan ini diperoleh dari hasil rata-rata total peneriman sebesar Rp. 1.268.473,68/bulan dikurang total biaya (TC) sebesar Rp. 993.507,48/bulan. Sehinga total pendapatan yang diperoleh pencari kepiting rata-rata sebesar Rp 274.966,20/bulan. Nilai pendapatan ini merupakan pendapatan bersih yang diperoleh pencari kepiting didaerah penelitian Desa Pasar Ngalam Kecamatan Air Periukan Kabupaten Seluma.

Pendapatan nelayan pencari kepiting bakau ini dapat di kategorikan masih rendah bila digunakan untuk memenuhi kebutuhan sehari-harinya. Karena dalam menangkap kepiting bakau, biasanya nelayan masih memakai alat tangkap yang masih sederhana atau bersifat tradisional. Selain itu juga biaya tenaga kerja yang dihitung dalam penelitian ini adalah biaya implisit yang seharusnya menjadi penerimaan bagi nelayan pencari kepiting bakau.

\section{KESIMPULAN}

Berdasarkan hasil penelitian menunjukkan bahwa pendapatan Nelayan Pencari Kepiting Bakau Di Desa Pasar Ngalam Kecamatan Air Periukan Kabupaten Seluma Propinsi Bengkulu sebesar Rp 274.966,20/bulan. 
Rita Feni, Edy Marwan, Fithri Mufriantie, Sukardi. Pendapatan Nelayan Pencari Kepiting Bakau Di Desa Pasar Ngalam Kecamatan Air Periukan Kabupaten Seluma Propinsi Bengkulu

\section{DAPTAR PUSTAKA}

Anonim. 2018. Potensi Usaha dan Peluang Investasi Kelautan dan Perikanan Provinai Bengkulu. Dirjen Penguatan Daya Saing Produk Kelautan dan perikanan. Bengkulu

Adisasmita, R. 2015. Pembangunan Wilayah. Graha Ilmu. Yogyakarta.

Badan Konservasi Sumberdaya Alam Bengkulu. 2013. Konservasi Kawasan Cagar Alam Pasar Ngalam. hhtp://bksdabengkulu.org/.

H. kordi K.M, Ghufron, 2012, Ekosistem Mangrove : Potensi, Fungsi, dan Pengelolaan, Rineka Cipta, Jakarta -------, 2011. Budi Daya 22 Komoditas Laut untuk Konsumsi Lokal dan Ekspor. Lily Publisher. Yogyakarta. -, 2010. Marikultur (Prinsip dan Pratik Budi Daya Laut). Andi.Yogyakarta.

http//: Kaltim.Tribunnews.com. 2015. Menteri Susi pudjiastuti revisi peraturan tentang- penangkapan-kepiting Suratiyah, K 2011. Ilmu Usahatani. Penebar Swadaya. Jakarta.

Mulyadi, S. 2007. Ekonomi Kelautan. Raja Grafindo Perseda. Jakarta.

Rahim dan Hastuti. 2007. Ekonomika Pertanian (Pengantar, Teori dan Kasus). Penebar Swadaya. Jakarta.

Riduwan, 2013. Dasar-dasar Statistika. Alfabeta. Bandung

Soekartawi. 2002 Analisis Usahatani. UI Press. Jakarta. 